\title{
Endemic Chikungunya Fever in Kenyan Children
}

2 Doris K. Nyamwaya ${ }^{1, a}$, Mark Otiende ${ }^{1, a}$, Donwilliams O. Omuoyo ${ }^{1}$, George Githinji ${ }^{1}$, Henry K.

3 Karanja ${ }^{1}$, John N. Gitonga ${ }^{1}$, Zaydah de Laurent ${ }^{1}$, James R. Otieno ${ }^{1}$, Rosemary Sang ${ }^{2}$, Everlyn

4 Kamau $^{1}$, Stanley Cheruiyot ${ }^{1}$, Edward Otieno ${ }^{1}$, Charles N. Agoti ${ }^{1}$, Philip Bejon ${ }^{1,3}$, Samuel M.

$5 \quad$ Thumbi $^{4,5,6}$, George M. Warimwe $\mathrm{e}^{1,3^{*}}$

6

$7 \quad{ }^{1}$ KEMRI-Wellcome Trust Research Programme, P.O. Box 230-80108, Kilifi, Kenya; ${ }^{2}$ KEMRI-Centre

8 for Virus Research, Nairobi, Kenya; ${ }^{3}$ Centre for Tropical Medicine and Global Health, University of

9 Oxford, Old Road Campus, NDM Research Building, Oxford OX3 7FZ, UK; ${ }^{4}$ Paul G Allen School

10 for Global Animal Health, Washington State University, Pullman, WA 99164-7090, USA; ${ }^{5}$ Centre for

11 Global Health Research, Kenya Medical Research Institute, P.O. Box 1578-4100, Kisumu, Kenya; ${ }^{6}$

12 Institute of Tropical and Infectious Diseases, University of Nairobi, P.O Box 19676 - 00202

13 Nairobi.

$15{ }^{a}$ contributed equally

*Correspondence:

17 George Warimwe, KEMRI-Wellcome Trust Research Programme, P.O. Box 230-80108, Kilifi,

18 Kenya

19 Email: gwarimwe@kemri-wellcome.org; Phone: +254(0)709 983000 
medRxiv preprint doi: https://doi.org/10.1101/2020.07.22.20116707; this version posted July 26, 2020. The copyright holder for this preprint

(which was not certified by peer review) is the author/funder, who has granted medRxiv a license to display the preprint in perpetuity.

It is made available under a CC-BY-NC-ND 4.0 International license .

\section{ABSTRACT}

22 Background. Chikungunya virus (CHIKV) was first identified in Tanzania in 1952. Several epidemics

23 including East Africa are described, but there are no descriptions of longitudinal surveillance of

24 endemic disease. Here, we estimate the incidence of CHIKV and describe viral phylogeny in coastal

25 Kenya.

26 Methods. Over a 5-year period (2014-2018), 11,708 febrile illnesses in 5,569 children visiting two

27 primary healthcare facilities linked to a demographic surveillance system in coastal Kenya were

28 recorded and blood samples obtained. Reverse-transcriptase PCR was used to identify CHIKF cases

29 in 3,500 children randomly selected from the 5,569 children.

30 Results. We found CHIKF to be endemic in this setting, associated with $12.7 \%$ (95\% CI 11.60, 13.80)

31 of all febrile presentations to primary healthcare. The prevalence of CHIKV infections among

32 asymptomatic children in a community survey was $0.7 \%$ (95\% CI $0.22,2.12$ ). CHIKF incidence

33 among children $<1$ year of age was 1703 cases/100,000-person years and 46 cases/100,000-person years

34 among children aged $\geq 10$ years. Recurrent CHIKF episodes, associated with fever and viraemia, were

35 observed among 19 of 170 children with multiple febrile episodes during the study period and

36 confirmed by genome sequencing. All sequenced viral genomes mapped to the ECSA genotype albeit

37 distinct from CHIKV strains associated with the 2004 East African epidemic.

38 Conclusions. CHIKF may be a substantial public health burden in primary healthcare on the East

39 African coast outside epidemic years, and recurrent infections are common.

\section{BACKGROUND}

42 Chikungunya fever (CHIKF) is a zoonotic mosquito-borne febrile illness characterised by acute, often

43 chronic, debilitating polyarthralgia and polyarthritis that can last for months to years [1-3]. The

44 disease is caused by chikungunya virus (CHIKV), a positive sense RNA virus in the family

45 Togaviridae that was first isolated from a febrile patient in Tanzania in 1952 [4]. CHIKV transmission 
medRxiv preprint doi: https://doi.org/10.1101/2020.07.22.20116707; this version posted July 26, 2020. The copyright holder for this preprint

(which was not certified by peer review) is the author/funder, who has granted medRxiv a license to display the preprint in perpetuity.

It is made available under a CC-BY-NC-ND 4.0 International license .

46 between humans is mainly mediated by the geographically widespread Aedes aegypti and Ae.

47 albopictus mosquitoes, with geographic spread and spillover from sylvatic transmission cycles in

48 monkeys thought to account for the periodic re-emergence of human disease outbreaks [5-8].

49 The CHIKV genome is approximately $11.8 \mathrm{~kb}$ in length and encodes four non-structural proteins

50 (nsP1 to nsP4) required for viral replication, three major structural proteins (the capsid protein, and

51 envelope proteins E1 and E2), and two small polypeptides (6K/TF and E3) [9]. Exposure to CHIKV

52 results in acquisition of protective virus neutralising antibodies that target the E2 protein, and is the

53 basis for ongoing efforts to develop CHIKF vaccines [10, 11]. Phylogenetic studies have defined three

54 CHIKV genotypes, namely East, Central and Southern Africa (ECSA), West Africa, and the Asian

55 genotype [12]. In 2004, CHIKV re-emerged in coastal Kenya causing one of the largest epidemics on

56 record, affecting millions of people as it spread along the Indian Ocean islands, India, southeast Asia

57 and Europe $[8,13,14]$. This epidemic was associated with emergence of the Indian Ocean Lineage

58 (IOL), which mapped within the ECSA genotype and included viruses with adaptive mutations in the

59 E1 protein that increased their transmissibility by Aedes albopictus mosquitoes $[15,16]$.

60 CHIKF epidemics are now frequently reported globally $[8,17]$, but despite its original discovery and

61 later re-emergence in East Africa, very little is known regarding inter-epidemic CHIKV exposure in

62 the region. CHIKF cases have previously been detected in children in Kenya and Tanzania during

63 inter-epidemic periods [18-20], which together with the high anti-CHIKV antibody seroprevalence

64 observed in these settings suggest endemic CHIKV transmission [21, 22]. To address these

65 knowledge gaps, we conducted a primary healthcare-based study linked to demographic surveillance

66 and community survey to estimate the prevalence and incidence of CHIKV infections among children

67 in Kilifi, coastal Kenya. Our study period, 2014 to 2018, included the most recent CHIKF epidemic

68 year, 2016 [23], allowing an unprecedented assessment of exposure risk and disease burden before,

69 during and after a CHIKF epidemic in this setting. 
medRxiv preprint doi: https://doi.org/10.1101/2020.07.22.20116707; this version posted July 26, 2020. The copyright holder for this preprint

(which was not certified by peer review) is the author/funder, who has granted medRxiv a license to display the preprint in perpetuity.

It is made available under a CC-BY-NC-ND 4.0 International license .

71

72

73

74

75

76

77

\section{METHODS}

\section{Study population}

We conducted a population-based observational cohort study between March 2014 and October 2018 at two dispensaries, Ngerenya and Pingilikani, based within the Kilifi Health Demographic Surveillance System (KHDSS) [24]. The KHDSS covers an area of $891 \mathrm{~km}^{2}$ with approximately 290,000 residents that are enumerated every four months at the household level [24]. Ngerenya and Pingilikani have different rates of mosquito-borne pathogen exposure as inferred from previous malaria studies; Ngerenya and environs experiences low intensity malaria transmission, whereas malaria transmission around Pingilikani is moderate [25]. However, no studies on arbovirus exposure had been conducted previously. Our approach was to screen children presenting with fever (axillary temperature of $\geq 37.5^{\circ} \mathrm{C}$ ) at the dispensaries for $\mathrm{CHIKV}$ infection by reverse-transcriptase polymerase chain reaction (RT-PCR). Children presenting at the dispensaries were linked to the KHDSS data using a unique identifier, allowing us to estimate incidence in the population, and to determine the influence of various demographic variables on the incidence estimates. Ethical approval was provided by the Kenya Medical Research Institute Scientific and Ethics Review Unit (SSC Nos. 3296, 2617 and 3149).

\section{CHIKV RT-PCR assays}

CHIKV infection was defined as detection of CHIKV viral RNA by RT-PCR using a published primer-probe set targeting the CHIKV non-structural protein 1 (nsP1) region[26], namely CHIKV 874 (5'-AAAGGGCAAACTCAGCTTCAC-3'), CHIKV 961 (5'-GCCTGGGCTCATCGTTATTC-3') and CHIKV 899-FAM (5'-FAM-CGCTGTGATACAGTGGTTTCGTGTG-TAMRA-3'). Briefly, $100 \mu 1$ of finger-prick blood samples collected at presentation to the dispensaries, and stored at $-80^{\circ} \mathrm{C}$, was used for total RNA isolation using TRIzol ${ }^{\mathrm{TM}}$ Reagent (ThermoFisher) as per manufacturer instructions. Presence of CHIKV viral RNA was then determined using the QuantiFast RT-PCR Kit (Qiagen) in a $25 \mu 1$ reaction with primers and probe at a final concentration of $100 \mathrm{nM}$ and $20 \mathrm{nM}$, respectively, and $5 \mu 1$ total RNA template. RT-PCR assays were done on a 7500 Real-Time PCR 
medRxiv preprint doi: https://doi.org/10.1101/2020.07.22.20116707; this version posted July 26, 2020. The copyright holder for this preprint

(which was not certified by peer review) is the author/funder, who has granted medRxiv a license to display the preprint in perpetuity.

It is made available under a CC-BY-NC-ND 4.0 International license .

97 System (Applied Biosystems) with cycling conditions as follows: $50^{\circ} \mathrm{C}$ for 20 minutes, $95^{\circ} \mathrm{C}$ for 15

98 minutes, followed by 45 cycles of $94^{\circ} \mathrm{C}$ for 15 seconds and $60^{\circ} \mathrm{C}$ for 1 minute. A second confirmatory

99 screen was performed on some of the RT-PCR positive samples using an assay targeting the CHIKV

$100 \mathrm{nsP} 4$ region as previously described[27]. For both assays, a positive result was defined as a cycle

101 threshold $(\mathrm{Ct})$ value of $<40$. Viral RNA from a cultured CHIKV isolate obtained from a febrile

102 Kenyan patient was used as a positive control, while RT-PCR mastermix without template was used

103 as a negative control.

\section{CHIKV genome sequencing and analysis}

105 RT-PCR positive CHIKV samples were sequenced using the Nanopore MinION technology following

106 PCR amplification using methods described in the PrimalSeq approach ${ }^{17}$. Full details of our

107 sequencing and bioinformatics workflow can be found in the Supplementary Material. In brief,

108 CHIKV-specific multiplex primers were designed using the Primal Scheme software and used for pre-

109 enrichment of CHIKV viral RNA in the samples using a multiplex PCR method. Barcodes and

110 sequencing adapters were ligated into each sample, after which all samples were pooled into a single

111 reaction tube and the library loaded on to a MinION sequencing device for sequencing. The sequences

112 generated in this study $(\mathrm{N}=10)$ were deposited in GenBank, accession numbers: MT526796-

113 MT526807. MUSCLE was used to align the Kilifi CHIKV genome sequences with those available in

114 GenBank from other geographical locations (see Supplementary Material). Maximum Likelihood

115 phylogenies were reconstructed from the alignment using RAxML[28] using the GTR substitution

116 model with 4 gamma categories $(\mathrm{GTR}+\mathrm{G} 4)$ and visualized in FigTree v1.4.4.

\section{Sampling and statistical analyses}

118 We selected a random sample of 3500 out of 5,669 children who visited the two dispensaries with

119 febrile illness. Associations between available demographic variables and CHIKV RT-PCR positivity

120 were assessed using odds ratios estimated using logistic regression models. CHIKF incidence within

121 the dispensary catchment area, defined as radius of $5 \mathrm{~km}$ from each dispensary, was expressed per

122100,000 person-years observed and incidence rate ratios (IRRs) comparing various demographic 
medRxiv preprint doi: https://doi.org/10.1101/2020.07.22.20116707; this version posted July 26, 2020. The copyright holder for this preprint

(which was not certified by peer review) is the author/funder, who has granted medRxiv a license to display the preprint in perpetuity.

It is made available under a CC-BY-NC-ND 4.0 International license .

123 variables determined by Poisson regression. Univariate analyses were performed using Chi2 test

124 (categorical variables) or the Mann-Whitney U test (continuous variables). All statistical analyses

125 were carried out in Stata $^{\mathrm{TM}}$ version 15 with a two-sided $\mathrm{p}$ value $<0.05$ used for statistical significance.

127 RESULTS

\section{CHIKV infections are common among children in coastal Kenya}

129 Between March 2014 and October 2018, there were 29,819 visits by children aged up to 15 years to

130 the two dispensaries (6,746 in Ngerenya, 23,073 in Pingilikani), of which 13,696 were febrile (Figure

131 1). Of the 13,696 fevers, 1,256 lacked a unique patient identifier and 732 samples were missing. After

132 these exclusions, there were 11,708 febrile visits from a total of 5,569 children (median 1 febrile visit

133 per child during the study period, IQR 1 - 2) eligible for CHIKV RT-PCR analysis (Figure 1).

134 A sample of 3,500 febrile children out of the 5,569 across the two dispensaries were randomly

135 selected and samples from their first (index) febrile episode during the study period screened for

136 CHIKV infection (Figure 1). The median age of these 3,500 children was 3.1 years (IQR 1.3 - 6.4),

137 with 1,701 being resident in Ngerenya and 1,799 in Pingilikani, respectively (Figure 1). Our study

138 period, 2014 to 2018, was at least 10 years since the 2004 CHIKF epidemic occurred in Kenya, with

$139 \sim 90 \%$ our study population having been born after that epidemic.

140 Of the 3,500 children 443 were RT-PCR positive (12.7\%, 95\% CI 11.60, 13.80; Table 1), with RT-

141 PCR positivity being twice as frequent in Ngerenya $(16.7 \%, 95 \%$ CI $15.00,18.54)$ than in Pingilikani

142 (8.8\%, 95\% CI 7.61, 10.24). Most of the 443 CHIKF cases had a clinical diagnosis of upper

143 respiratory tract infection (URTI) but in no instance was a diagnosis of CHIKF assigned (Table 1).

144 The treatments prescribed for the management of CHIKF cases were comparable to those for other

145 causes of fever at the dispensaries, but fewer antimalarials were prescribed for CHIKF cases (Table

146 1). CHIKF case prevalence was highest in 2016 (23.1\%), when an epidemic was reported in Kenya

147 [23], and was significantly lower in the pre- and post-epidemic years where it ranged between 5\% and 
medRxiv preprint doi: https://doi.org/10.1101/2020.07.22.20116707; this version posted July 26, 2020. The copyright holder for this preprint

(which was not certified by peer review) is the author/funder, who has granted medRxiv a license to display the preprint in perpetuity.

It is made available under a CC-BY-NC-ND 4.0 International license .

$1488 \%$ (Table 1). In contrast, the prevalence of asymptomatic CHIKV infections estimated by cross-

149 sectional sampling of a different group of 435 children in the same study location in 2016 was $0.7 \%$

150 (95\% CI 0.22, 2.12); this yielded a clinical-to-asymptomatic CHIKV infection ratio of 18:1 during the

151 epidemic year.

\section{Incidence of CHIKF in the community}

153 We calculated the incidence of CHIKF restricting our analysis to children aged up to 15 years whose

154 residence was within the dispensary catchment area. This represented a total of 139,840 person-years

155 of observation (pyo) over the study period at both locations. For the numerator (CHIKF cases), we

156 applied the observed CHIKV RT-PCR positivity rates (Table 1) to the total number of febrile children

157 presenting to the respective dispensary on the assumption that the case positive rate among the 3,500

158 we randomly selected would hold true for the remaining 2,069 samples.

159 The incidence of CHIKF during the study period was 340 cases/100,000 pyo (95\% CI 310, 373; Table

160 2). However, an inverse relationship was evident between CHIKF incidence and age, consistent with

161 acquisition of protective immunity against disease due to ongoing CHIKV exposure in this setting

162 (Table 2). CHIKF incidence was significantly higher in Ngerenya as compared to Pingilikani;

163 furthermore, while an increase in incidence was observed in Ngerenya during the 2016 CHIKF

164 epidemic, such an increase was not observed in Pingilikani where CHIKF incidence had been

165 gradually declining since 2014 (Table 2). Marked seasonality in CHIKF incidence was observed in

166 Pingilikani but not Ngerenya (Table 2) suggesting potential differences in ecological risk factors of

167 disease. A negative correlation was observed between CHIKF incidence and residential distance from

168 the dispensary at both locations, which likely reflected access to care (Table 2) as has been previously

169 reported for malaria incidence [29].

\section{Recurrent CHIKF episodes}

171 We determined whether recurrent CHIKF episodes occurred in our study population. To do this we

172 identified all 443 children with first or only episodes of CHIKF and screened all subsequent samples 
medRxiv preprint doi: https://doi.org/10.1101/2020.07.22.20116707; this version posted July 26, 2020. The copyright holder for this preprint

(which was not certified by peer review) is the author/funder, who has granted medRxiv a license to display the preprint in perpetuity.

It is made available under a CC-BY-NC-ND 4.0 International license .

173 collected during febrile episodes during the period 2014-2018. We defined recurrent episodes as

174 CHIKV RT-PCR positivity during these subsequent febrile dispensary visits. Of the 443 index cases,

175170 presented to the dispensary with fever on at least one other occasion during the study period,

176 contributing a total of 320 subsequent febrile dispensary visits with varying durations since the

177 corresponding index CHIKF case (Figure 1). Of the 170 children, 19 (11.2\%, 95\% CI 6.86, 16.90)

178 were CHIKV RT-PCR positive on at least one subsequent febrile episode (Figures 1 and 2). The

179 duration between the index and the subsequent RT-PCR positive febrile episodes ranged from 2 to 43

180 months (Figure 2, and Supplementary Material Table S2). Eighteen of the 19 CHIKV RT-PCR

181 positive cases were detected during or after the 2016 CHIKF epidemic year. Neither age, sex nor

182 geographic location were statistically associated with recurrent episodes of CHIKF (Chi2 test $p>0.05$

183 for all) and the RT-PCR Ct values and clinical diagnoses were comparable between the index case

184 and corresponding subsequent timepoints (Supplementary Material Figure S2 and Table S2).

\section{Viral phylogeny}

186 We attempted to sequence all index and subsequent RT-PCR positive samples from the 19 children

187 with recurrent CHIKF episodes (Figure 2). Complete and partial genome coding sequences were

188 generated from 10 samples, including an additional index sample with a low $\mathrm{Ct}$ value $(\mathrm{Ct}=19)$ from a

189 child who did not experience recurrent CHIKF episodes during the study period. All CHIKV genomes

190 generated in this study mapped to the ECSA genotype, albeit distinct from the clade containing the

191 IOL strains that emerged during the 2004 epidemic and the clade including genomes from CHIKF

192 patients sampled in Mandera, northern Kenya, during the 2016 epidemic (Figure 3). The E1 A226V

193 mutation, associated with adaptation and increased transmissibility by Aedes albopictus [15], was

194 absent from all sequences sampled in Kenya [23]. Time-resolved phylogenies showed strong temporal

195 clustering of CHIKV sequences from coastal Kenya that may suggest antigenic changes over time

196 driven by acquisition of herd immunity (Figure 3). Index-recurrent episode case genome sequence

197 pairs were available for four children with respective time intervals of 2.9, 3.5, 22.3 and 28.3 months

198 between the index and recurrent episodes (Figure 3). The degree of relatedness of the sequence pairs 
medRxiv preprint doi: https://doi.org/10.1101/2020.07.22.20116707; this version posted July 26, 2020. The copyright holder for this preprint

(which was not certified by peer review) is the author/funder, who has granted medRxiv a license to display the preprint in perpetuity.

It is made available under a CC-BY-NC-ND 4.0 International license .

199 was similarly time-dependent, with the sequence pair with the longest time interval (28.3 months)

200 being most divergent (Figure 3).

201

202 DISCUSSION

203 In summary, we find that CHIKF is endemic in coastal Kenya with the case burden being particularly

204 high in young children aged $<1$ year. Our population-based cohort approach in primary healthcare

205 facilities could detect an increase in CHIKF cases during the 2016 epidemic, supporting the utility of

206 such a surveillance framework in the early detection of CHIKF epidemics. During the epidemic year

207 an increase in CHIKF incidence was only noted in Ngerenya while that in Pingilikani (located

208 approximately 40km south of Ngerenya) had been declining [25]; in our dataset, clinical malaria

209 accounted for 57\% of all fevers in Pingilikani but only 5\% in Ngerenya, while URTI accounted for

$21070 \%$ of all fevers in Ngerenya but only $10 \%$ in Pingilikani. We observed significant CHIKF

211 incidence in both locations, and an inverse relationship between CHIKF incidence and age was

212 evident at both locations. This suggests that immunity is acquired in older children, and that CHIKF

213 transmission is significant in both locations despite the varying malaria ecology.

214 Consistent with previous reports of CHIKF in children in East Africa [19, 30], none of the patients in

215 this study had a clinical diagnosis of CHIKF or reported symptoms of joint pathology. Nineteen

216 children were CHIKV RT-PCR positive during subsequent febrile episodes, with viral genome

217 sequences from these recurrent episodes not showing high degrees of relatedness to the index case.

218 Chronic relapsing and remitting CHIKF symptoms have been observed in adult patients during

219 previous epidemics, as an inflammatory post-infectious arthropathy [31-33] with viral RNA detected

220 in the joint tissues in one study [34]. However, we are aware of no reports of recurrent discrete

221 CHIKF episodes associated with reinfection. This may simply be due to the rarity of longitudinal

222 surveillance studies for CHIKF, particularly in children. In our study, the relatedness of virus

223 genomes from first and second infections in the same child was similar to the relatedness of virus

224 genomes from different children, suggesting that these were reinfections rather than relapses. 
medRxiv preprint doi: https://doi.org/10.1101/2020.07.22.20116707; this version posted July 26, 2020. The copyright holder for this preprint

(which was not certified by peer review) is the author/funder, who has granted medRxiv a license to display the preprint in perpetuity.

It is made available under a CC-BY-NC-ND 4.0 International license .

225 Neutralising antibodies that develop following CHIKV infection have been shown to correlate with

226 decreased risk of clinical illness in a longitudinal study in the Phillipines [35, 36], though CHIKF

227 cases in that study were all due to the Asian CHIKV genotype. The possibility that the ECSA

228 genotype viruses, which tend to be more diverse [12] and associated with a higher clinical disease

229 burden than Asian genotypes [37], results in a variable immune response in children in East Africa

230 needs to be ruled out. The inverse relationship between age and incidence of CHIKF suggests that

231 there is an acquisition of protective immunity, although the recurrent infections suggest that this

232 immunity is not rapidly acquired in some children.

233 Only finger-prick whole blood samples for RT-PCR analysis were available for this study, thus

234 precluding any immunological work. Future longitudinal studies with serial blood sampling for

235 immunological assays will help determine the natural course of infection, including duration of

236 viraemia, and identify host and viral factors that may underlie the occurrence of CHIKF relapses in

237 coastal Kenya.

238 Consistent with other reports of CHIKV strains circulating in East Africa [12, 23], the viral genomes

239 generated in this study all mapped to the ECSA genotype. Further, in contrast to the 2016 CHIKF

240 epidemic viruses from Mandera (northern Kenya) that formed a single well-supported clade,

241 sequences from coastal Kenya were highly diverse and fell within multiple well-supported clades that

242 whose divergence increased with time. Together, these data suggest ongoing endemic CHIKV

243 transmission at the Kenyan coast possibly sustained through frequent emergence of diverse CHIKV

244 strains from local sylvatic transmission cycles [6].

245 Our data and that from others in the region [30] further reinforce the need for inclusion of CHIKF

246 high on the list of differential diagnoses to consider when faced with a febrile child at primary

247 healthcare facilities in coastal Kenya. Access to rapid diagnostics would be of value in antibiotic

248 stewardship, and control of transmission in the community would substantially reduce the burden on

249 healthcare facilities. Further studies on the associated clinical outcomes, including the incidence of 
medRxiv preprint doi: https://doi.org/10.1101/2020.07.22.20116707; this version posted July 26, 2020. The copyright holder for this preprint

(which was not certified by peer review) is the author/funder, who has granted medRxiv a license to display the preprint in perpetuity.

It is made available under a CC-BY-NC-ND 4.0 International license .

250 severe ('atypical') manifestations of CHIKF, should help determine the wider public health

251 significance of CHIKF in coastal Kenya.

\section{FUNDING}

254 This work was commissioned by the National Institute for Health Research (NIHR) Global Health

255 Research programme [16/136/33] using UK aid from the UK Government. The views expressed in

256 this publication are those of the authors and not necessarily those of the NIHR or the Department of

257 Health and Social Care. GMW is supported by an Oak foundation fellowship and a Wellcome Trust

258 grant [grant number 203077_Z_16_Z].

259

260 CONFLICT OF INTEREST

261 All authors declare no conflicts of interest.

262

263 ACKNOWLEDGEMENTS

264 This manuscript was submitted for publication with permission from the Director of the Kenya

265 Medical Research Institute.

\section{REFERENCES}

268 1. Robinson MC. An epidemic of virus disease in Southern Province, Tanganyika Territory, in 1952-53. I. Clinical features. Trans R Soc Trop Med Hyg 1955; 49(1): 28-32. 
medRxiv preprint doi: https://doi.org/10.1101/2020.07.22.20116707; this version posted July 26, 2020. The copyright holder for this preprint (which was not certified by peer review) is the author/funder, who has granted medRxiv a license to display the preprint in perpetuity.

It is made available under a CC-BY-NC-ND 4.0 International license .

270 2. Lumsden WH. An epidemic of virus disease in Southern Province, Tanganyika Territory, in

271 1952-53. II. General description and epidemiology. Trans R Soc Trop Med Hyg 1955; 49(1):

$272 \quad 33-57$.

273 3. Tritsch SR, Encinales L, Pacheco N, et al. Chronic joint pain 3 years after chikungunya virus 274 infection largely characterized by relapsing-remitting symptoms. J Rheumatol 2019.

275 4. Ross RW. The Newala epidemic. III. The virus: isolation, pathogenic properties and 276 relationship to the epidemic. J Hyg (Lond) 1956; 54(2): 177-91.

277 5. Althouse BM, Guerbois M, Cummings DAT, et al. Role of monkeys in the sylvatic cycle of 278 chikungunya virus in Senegal. Nat Commun 2018; 9(1): 1046.

279 6. Eastwood G, Sang RC, Guerbois M, Taracha ELN, Weaver SC. Enzootic Circulation of 280 Chikungunya Virus in East Africa: Serological Evidence in Non-human Kenyan Primates.

$281 \quad$ Am J Trop Med Hyg 2017; 97(5): 1399-404.

282 7. Weaver SC, Lecuit M. Chikungunya virus and the global spread of a mosquito-borne disease.

$283 \quad$ N Engl J Med 2015; 372(13): 1231-9.

284 8. Wahid B, Ali A, Rafique S, Idrees M. Global expansion of chikungunya virus: mapping the 285 64-year history. Int J Infect Dis 2017; 58: 69-76.

2869 9. Voss JE, Vaney MC, Duquerroy S, et al. Glycoprotein organization of Chikungunya virus 287 particles revealed by X-ray crystallography. Nature 2010; 468(7324): 709-12.

288 10. Rezza G, Weaver SC. Chikungunya as a paradigm for emerging viral diseases: Evaluating disease impact and hurdles to vaccine development. PLoS Negl Trop Dis 2019; 13(1):

291 11. Gouglas D, Thanh Le T, Henderson K, et al. Estimating the cost of vaccine development 292

12. Volk SM, Chen R, Tsetsarkin KA, et al. Genome-scale phylogenetic analyses of chikungunya virus reveal independent emergences of recent epidemics and various evolutionary rates. $\mathbf{J}$ Virol 2010; 84(13): 6497-504. 
medRxiv preprint doi: https://doi.org/10.1101/2020.07.22.20116707; this version posted July 26, 2020. The copyright holder for this preprint

(which was not certified by peer review) is the author/funder, who has granted medRxiv a license to display the preprint in perpetuity.

It is made available under a CC-BY-NC-ND 4.0 International license .

297 13. Chretien JP, Anyamba A, Bedno SA, et al. Drought-associated chikungunya emergence along 298 coastal East Africa. Am J Trop Med Hyg 2007; 76(3): 405-7.

299 14. Sergon K, Njuguna C, Kalani R, et al. Seroprevalence of Chikungunya virus (CHIKV)

$300 \quad$ infection on Lamu Island, Kenya, October 2004. Am J Trop Med Hyg 2008; 78(2): 333-7.

$301 \quad$ 15. Tsetsarkin KA, Vanlandingham DL, McGee CE, Higgs S. A single mutation in chikungunya

302 virus affects vector specificity and epidemic potential. PLoS Pathog 2007; 3(12): e201.

303 16. Weaver SC, Forrester NL. Chikungunya: Evolutionary history and recent epidemic spread.

$304 \quad$ Antiviral Res 2015; 120: 32-9.

305 17. Nsoesie EO, Kraemer MU, Golding N, et al. Global distribution and environmental suitability

306 for chikungunya virus, 1952 to 2015. Euro Surveill 2016; 21(20).

307 18. Kajeguka DC, Kaaya RD, Mwakalinga S, et al. Prevalence of dengue and chikungunya virus

308 infections in north-eastern Tanzania: a cross sectional study among participants presenting

309 with malaria-like symptoms. BMC Infect Dis 2016; 16: 183.

310 19. Chipwaza B, Mugasa JP, Selemani M, et al. Dengue and Chikungunya fever among viral

311 diseases in outpatient febrile children in Kilosa district hospital, Tanzania. PLoS Negl Trop

$312 \quad$ Dis 2014; 8(11): e 3335.

313 20. Hertz JT, Munishi OM, Ooi EE, et al. Chikungunya and dengue fever among hospitalized

314 febrile patients in northern Tanzania. Am J Trop Med Hyg 2012; 86(1): 171-7.

315 21. Weller N, Clowes P, Dobler G, et al. Seroprevalence of alphavirus antibodies in a cross-

316 sectional study in southwestern Tanzania suggests endemic circulation of chikungunya. PLoS

$317 \quad$ Negl Trop Dis 2014; 8(7): e2979.

318 22. LaBeaud AD, Banda $\mathrm{T}$, Brichard $\mathrm{J}$, et al. High rates of o'nyong nyong and Chikungunya virus

319 transmission in coastal Kenya. PLoS Negl Trop Dis 2015; 9(2): e0003436.

320 23. Maljkovic Berry I, Eyase F, Pollett S, et al. Global Outbreaks and Origins of a Chikungunya

321 Virus Variant Carrying Mutations Which May Increase Fitness for Aedes aegypti:

322 Revelations from the 2016 Mandera, Kenya Outbreak. Am J Trop Med Hyg 2019; 100(5):

$323 \quad 1249-57$. 
medRxiv preprint doi: https://doi.org/10.1101/2020.07.22.20116707; this version posted July 26, 2020. The copyright holder for this preprint (which was not certified by peer review) is the author/funder, who has granted medRxiv a license to display the preprint in perpetuity.

It is made available under a CC-BY-NC-ND 4.0 International license .

324 24. Scott JA, Bauni E, Moisi JC, et al. Profile: The Kilifi Health and Demographic Surveillance

325 System (KHDSS). Int J Epidemiol 2012; 41(3): 650-7.

326 25. Mogeni P, Williams TN, Fegan G, et al. Age, Spatial, and Temporal Variations in Hospital Admissions with Malaria in Kilifi County, Kenya: A 25-Year Longitudinal Observational Study. PLoS Med 2016; 13(6): e1002047.

329 26. Lanciotti RS, Kosoy OL, Laven JJ, et al. Chikungunya virus in US travelers returning from $330 \quad$ India, 2006. Emerg Infect Dis 2007; 13(5): 764-7.

331 27. Pabbaraju K, Wong S, Gill K, Fonseca K, Tipples GA, Tellier R. Simultaneous detection of Zika, Chikungunya and Dengue viruses by a multiplex real-time RT-PCR assay. J Clin Virol 2016; 83: 66-71.

28. Kozlov AM, Darriba D, Flouri T, Morel B, Stamatakis A. RAxML-NG: a fast, scalable and

29. Bejon P, Williams TN, Nyundo C, et al. A micro-epidemiological analysis of febrile malaria in Coastal Kenya showing hotspots within hotspots. Elife 2014; 3: e02130.

30. Waggoner J, Brichard J, Mutuku F, et al. Malaria and Chikungunya Detected Using Molecular Diagnostics Among Febrile Kenyan Children. Open Forum Infect Dis 2017; 4(3):

342 31. Couturier E, Guillemin F, Mura M, et al. Impaired quality of life after chikungunya virus infection: a 2-year follow-up study. Rheumatology (Oxford) 2012; 51(7): 1315-22.

344 32. Staikowsky F, Le Roux K, Schuffenecker I, et al. Retrospective survey of Chikungunya disease in Reunion Island hospital staff. Epidemiol Infect 2008; 136(2): 196-206.

33. Chang AY, Encinales L, Porras A, et al. Frequency of Chronic Joint Pain Following

349 34. Hoarau JJ, Jaffar Bandjee MC, Krejbich Trotot P, et al. Persistent chronic inflammation and infection by Chikungunya arthritogenic alphavirus in spite of a robust host immune response. J Immunol 2010; 184(10): 5914-27. 
medRxiv preprint doi: https://doi.org/10.1101/2020.07.22.20116707; this version posted July 26, 2020. The copyright holder for this preprint

(which was not certified by peer review) is the author/funder, who has granted medRxiv a license to display the preprint in perpetuity.

It is made available under a CC-BY-NC-ND 4.0 International license .

352 35. Yoon IK, Alera MT, Lago CB, et al. High rate of subclinical chikungunya virus infection and

353 association of neutralizing antibody with protection in a prospective cohort in the Philippines.

$354 \quad$ PLoS Negl Trop Dis 2015; 9(5): e0003764.

355 36. Yoon IK, Srikiatkhachorn A, Alera MT, Fernandez S, Cummings DAT, Salje H. Pre-existing

356 chikungunya virus neutralizing antibodies correlate with risk of symptomatic infection and

357 subclinical seroconversion in a Philippine cohort. Int J Infect Dis 2020.

358 37. Bustos Carrillo F, Collado D, Sanchez N, et al. Epidemiological Evidence for Lineage-

359 Specific Differences in the Risk of Inapparent Chikungunya Virus Infection. J Virol 2019;

360 93(4).

361

362

363

364

365

366

367

368

369

370

371

372 
medRxiv preprint doi: https://doi.org/10.1101/2020.07.22.20116707; this version posted July 26, 2020. The copyright holder for this preprint (which was not certified by peer review) is the author/funder, who has granted medRxiv a license to display the preprint in perpetuity.

It is made available under a CC-BY-NC-ND 4.0 International license.

\section{TABLES}

374 Table 1. Demographic characteristics of study participants

\section{CHIKF cases $/ \mathbf{N} \quad$ Crude OR $(95 \%$ CI $) \quad$ P value \\ $(\%)$}

\section{Dispensary}

$\begin{array}{cccc}\text { Ngerenya (Kilifi North) } & 284 / 1701(16.7) & \text { Ref } & \\ \text { Pingilikani (Kilifi South) } & 159 / 1799(8.8) & 0.5(0.39,0.59) & <0.001\end{array}$

\section{Gender}

\begin{tabular}{cccc}
\hline Female & $221 / 1647(13.4)$ & Ref & \\
\hline Male & $222 / 1853(12.0)$ & $0.9(0.72,1.07)$ & 0.2
\end{tabular}

\begin{tabular}{|c|c|c|c|c|}
\hline Age (years) & & & & \\
\hline & $<1$ & 79/601 (13.1) & Ref & \\
\hline & 1 to $<5$ & $220 / 1700(12.9)$ & $1.0(0.75,1.29)$ & 0.9 \\
\hline & 5 to $<10$ & $109 / 899(12.1)$ & $0.9(0.67,1.24)$ & 0.6 \\
\hline & 10 to 15 & $35 / 300(11.7)$ & $0.9(0.57,1.33)$ & 0.5 \\
\hline \multicolumn{5}{|l|}{ Year } \\
\hline & 2014 & $43 / 509(8.4)$ & Ref & \\
\hline & 2015 & $48 / 869(5.5)$ & $0.6(0.41,0.97)$ & 0.04 \\
\hline & 2016 & $208 / 902(23.1)$ & $3.2(2.29,4.60)$ & $<0.001$ \\
\hline & 2017 & $108 / 674(16.0)$ & $2.1(1.42,3.01)$ & $<0.001$ \\
\hline & 2018 & $36 / 546(6.6)$ & $0.8(0.48,1.21)$ & 0.3 \\
\hline
\end{tabular}

\section{Season}

\begin{tabular}{cccc} 
Jan - Mar & $142 / 855(16.6)$ & Ref & \\
Apr - Jun & $134 / 1070(12.5)$ & $0.7(0.56,0.93)$ & 0.01 \\
\hline Jul - Sep & $97 / 939(10.3)$ & $0.6(0.44,0.76)$ & $<0.001$ \\
\hline Oct - Dec & $70 / 636(11.0)$ & $0.6(0.46,0.84)$ & 0.002
\end{tabular}


medRxiv preprint doi: https://doi.org/10.1101/2020.07.22.20116707; this version posted July 26, 2020. The copyright holder for this preprint (which was not certified by peer review) is the author/funder, who has granted medRxiv a license to display the preprint in perpetuity.

It is made available under a CC-BY-NC-ND 4.0 International license .

\section{Clinical diagnosis}

\begin{tabular}{rccc}
\hline Other & $61 / 661(9.2)$ & Ref & \\
Malaria & $83 / 690(12.0)$ & $1.3(0.95,1.91)$ & 0.1 \\
\hline Pneumonia & $27 / 300(9.0)$ & $1.0(0.60,1.56)$ & 0.9 \\
\hline URTI & $218 / 1428(15.3)$ & $1.8(1.31,2.39)$ & $<0.001$ \\
\hline Gastroenteritis & $14 / 95(14.7)$ & $1.7(0.91,3.18)$ & 0.1 \\
\hline Undifferentiated fever & $40 / 326(12.3)$ & $1.4(0.90,2.10)$ & 0.1 \\
\hline
\end{tabular}

Treatment

\begin{tabular}{rccc} 
Antibiotic & $313 / 2393(13.1)$ & $1.1(0.90,1.40)$ & 0.3 \\
Antimalarial & $117 / 1104(10.6)$ & $0.8(0.60,0.94)$ & 0.01 \\
\hline Other & $41 / 291(14.1)$ & $1.1(0.81,1.62)$ & 0.4
\end{tabular}

375

376

377 Table 2. Incidence of CHIKF in the study population

\begin{tabular}{|c|c|c|c|c|}
\hline & $N=74,799$ person-years & $\begin{array}{l}\text { nya } \\
\text { rson-years }\end{array}$ & $N=65,041$ person-years & $\begin{array}{l}\text { kani } \\
\text { rson-years }\end{array}$ \\
\hline & $\begin{array}{l}\text { Incidence } \\
\text { (95\% CI) }\end{array}$ & $\begin{array}{c}\text { IRRs } \\
(95 \% \mathrm{CI})\end{array}$ & $\begin{array}{l}\text { Incidence } \\
(95 \% \mathrm{CI})\end{array}$ & $\begin{array}{c}\text { IRRs } \\
(95 \% \mathrm{CI})\end{array}$ \\
\hline Overall incidence & $408(363,457)$ & - & $267(228,311)$ & - \\
\hline \multicolumn{5}{|l|}{ Year } \\
\hline 2014 & - & - & $643(513,794)$ & Ref \\
\hline 2015 & $67(32,123)$ & Ref & $289(205,397)$ & $0.43(0.30,0.64)$ \\
\hline 2016 & $1205(1035,1395)$ & $18.08(9.56,34.18)$ & $187(120,279)$ & $0.28(0.18,0.44)$ \\
\hline 2017 & $611(493,750)$ & $9.17(4.77,17.61)$ & $62(27,122)$ & $0.09(0.05,0.19)$ \\
\hline
\end{tabular}


medRxiv preprint doi: https://doi.org/10.1101/2020.07.22.20116707; this version posted July 26, 2020. The copyright holder for this preprint (which was not certified by peer review) is the author/funder, who has granted medRxiv a license to display the preprint in perpetuity. It is made available under a CC-BY-NC-ND 4.0 International license .

$2018 \quad 104(56,178) \quad 1.57(0.69,3.57) \quad 93(44,170) \quad 0.14(0.07,0.27)$

\section{Gender}

$\begin{array}{ccccc}\text { Female } & 382(321,452) & \text { Ref } & 328(268,398) & \text { Ref } \\ \text { Male } & 432(368,505) & 1.13(0.90,1.42) & 207(160,264) & 0.63(0.46,0.86)\end{array}$

\section{Age (years)}

\begin{tabular}{rcccc}
$<1$ & $2209(1776,2715)$ & Ref & $1198(856,1631)$ & Ref \\
\hline 1 to $<5$ & $791(670,927)$ & $0.36(0.28,0.46)$ & $587(476,717)$ & $0.49(0.34,0.71)$ \\
\hline 5 to $<10$ & $198(146,263)$ & $0.09(0.06,0.13)$ & $76(44,124)$ & $0.06(0.04,0.11)$ \\
\hline 10 to 15 & $24(9,52)$ & $0.01(0.005,0.02)$ & $68(38,112)$ & $0.06(0.03,0.10)$
\end{tabular}

\section{Distance from}

dispensary $(\mathrm{Km})$

\begin{tabular}{rcccc}
\hline$<1$ & $800(531,1156)$ & Ref & $560(306,939)$ & Ref \\
\hline 1 to $<2$ & $930(742,1152)$ & $1.16(0.76,1.79)$ & $1038(760,1384)$ & $1.85(1.02,3.37)$ \\
\hline 2 to $<3$ & $657(531,804)$ & $0.82(0.54,1.25)$ & $837(658,1049)$ & $1.50(0.85,2.65)$ \\
\hline 3 to $<4$ & $513(396,654)$ & $0.64(0.41,1.00)$ & $224(128,363)$ & $0.40(0.20,0.82)$ \\
\hline 4 to $<5$ & $118(70,186)$ & $0.15(0.08,0.27)$ & $118(59,211)$ & $0.21(0.10,0.46)$ \\
\hline 5 to $<6$ & $34(13,74)$ & $0.04(0.02,0.10)$ & $20(7,43)$ & $0.04(0.01,0.09)$
\end{tabular}

\section{Season}

\begin{tabular}{ccccc} 
Jan - Mar & $463(371,572)$ & Ref & $227(160,312)$ & Ref \\
Apr - Jun & $348(269,444)$ & $0.75(0.54,1.04)$ & $528(422,651)$ & $2.33(1.58,3.42)$ \\
& & & & \\
\hline Jul - Sep & $423(335,527)$ & $0.91(0.67,1.24)$ & $234(166,321)$ & $1.03(0.66,1.62)$ \\
Oct - Dec & $394(304,503)$ & $0.85(0.62,1.17)$ & $50(20,103)$ & $0.22(0.09,0.49)$
\end{tabular}


medRxiv preprint doi: https://doi.org/10.1101/2020.07.22.20116707; this version posted July 26, 2020. The copyright holder for this preprint

(which was not certified by peer review) is the author/funder, who has granted medRxiv a license to display the preprint in perpetuity.

It is made available under a CC-BY-NC-ND 4.0 International license .

\section{FIGURE LEGENDS}

382 Figure 1: Study population. The flow of study participants, reasons for exclusion and results from

383 CHIK RT-PCR screening are shown.

384 Figure 2: Recurrent CHIKF episodes. The distribution of febrile episodes for each of 19 children

385 who had at least two CHIKV RT-PCR positive febrile episodes is shown. The timing of the CHIKV

386 RT-PCR positive results is shown, with the index episode shown as the first data point in the follow

387 up timeline. Children with prefix 'NGE' were resident in Ngerenya and those with 'PIN' from

388 Pingilikani, respectively. Further details of these children can be found in Supplementary Material

389 Table S2.

390 Figure 3: Phylogenetic analysis of CHIKV genomes from Kenya. BEAST MCC tree of 123 ECSA

391 genomes collected across the world, including 24 from Kenya is shown in the left panel. On the right

392 panel is an extraction highlighting the CHIKV sequences generated in this study. The tips are

393 coloured according to geographic location or child identity (as in Figure 2, for those with paired

394 index-recurrent episode sequence pairs), with posterior probability support shown for select nodes

395 with probability $>0.8$. The same and more detailed MCC tree can be found in the Supplementary

396 Material Figure S1.

397

398

399

400

401

402

403

404 
medRxiv preprint doi: https://doi.org/10.1101/2020.07.22.20116707; this version posted July 26, 2020. The copyright holder for this preprint (which was not certified by peer review) is the author/funder, who has granted medRxiv a license to display the preprint in perpetuity.

It is made available under a CC-BY-NC-ND 4.0 International license .

405

406

407

408 FIGURES

$409 \quad$ Figure 1

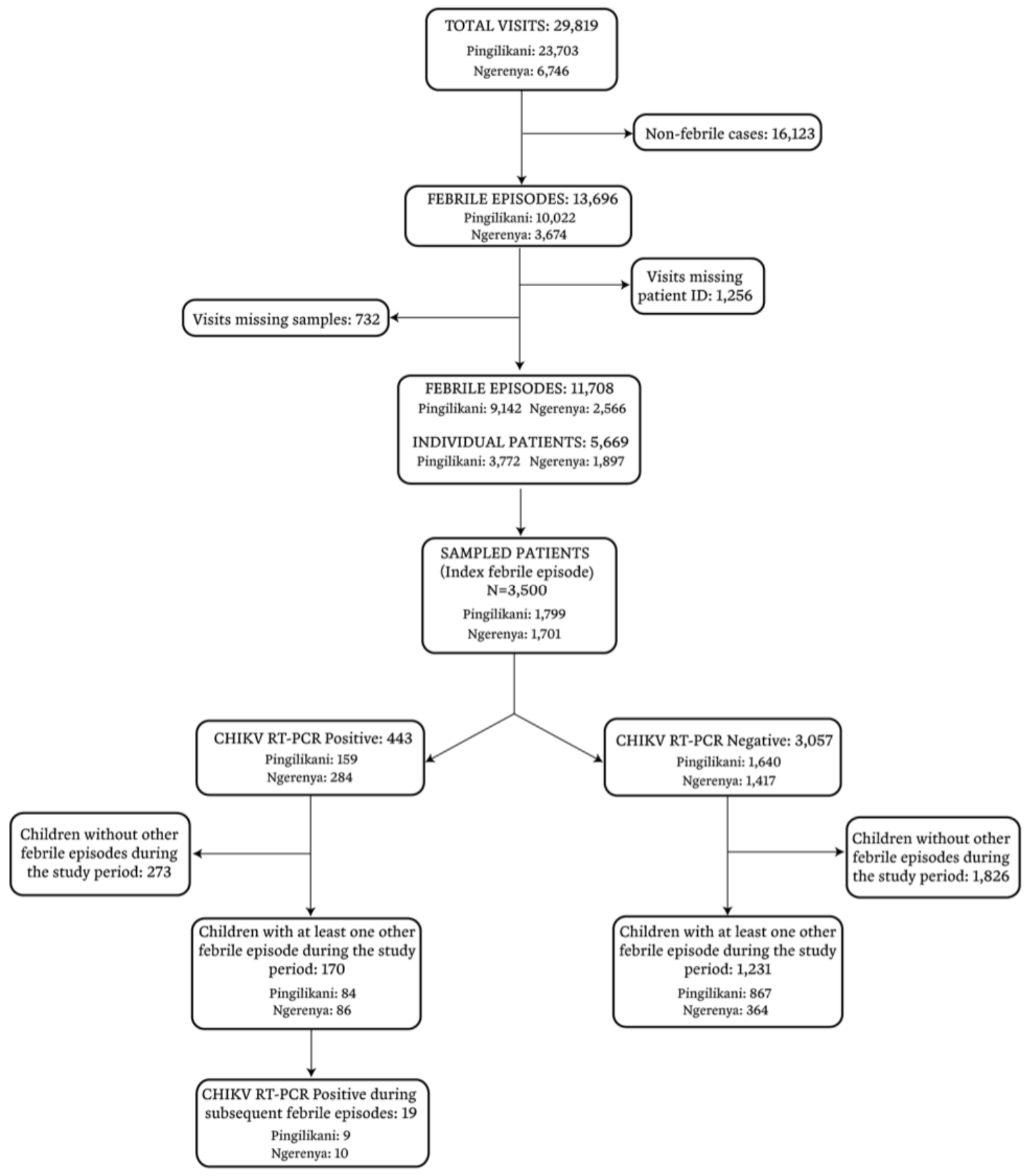


medRxiv preprint doi: https://doi.org/10.1101/2020.07.22.20116707; this version posted July 26, 2020. The copyright holder for this preprint (which was not certified by peer review) is the author/funder, who has granted medRxiv a license to display the preprint in perpetuity. It is made available under a CC-BY-NC-ND 4.0 International license.

411

412 Figure 2

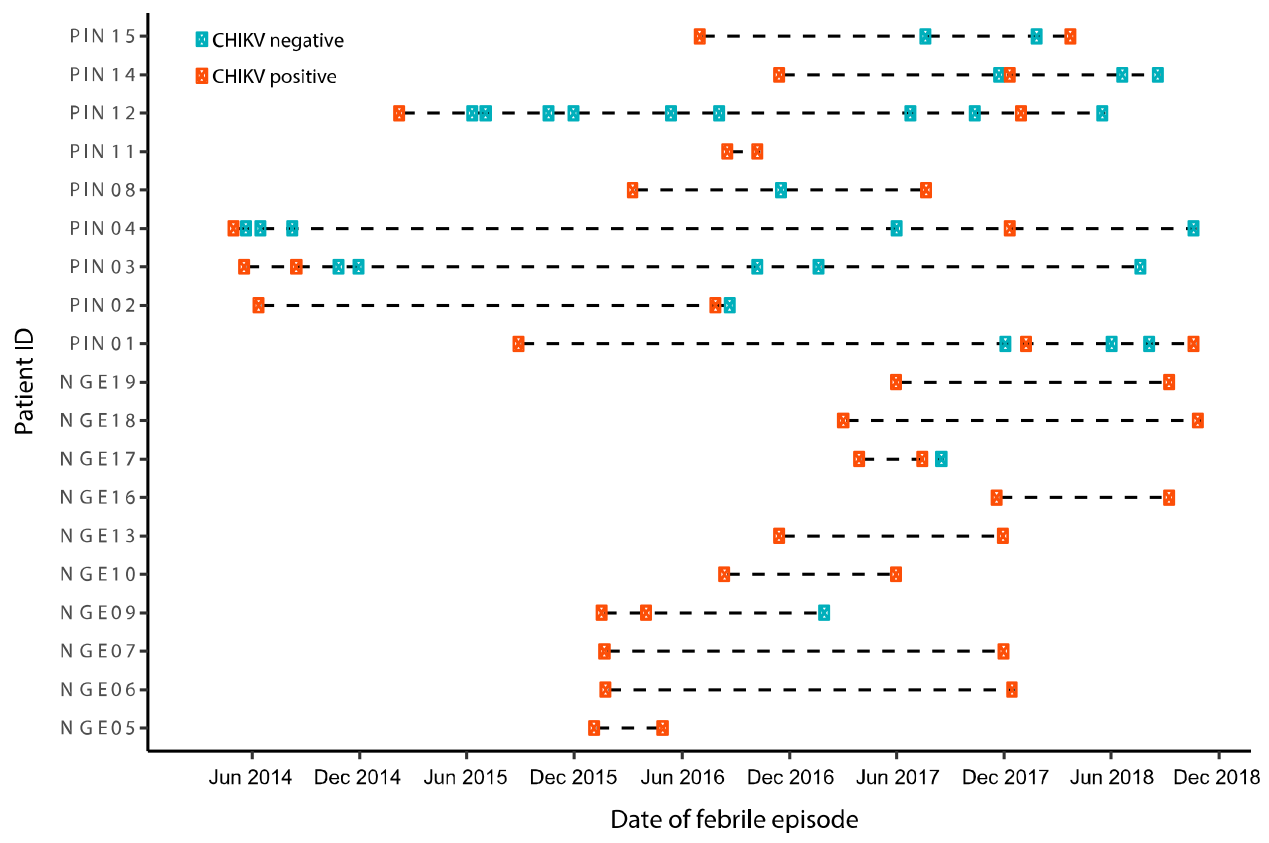

414

415

416

417

418

419

420

421

422

423

424 
medRxiv preprint doi: https://doi.org/10.1101/2020.07.22.20116707; this version posted July 26, 2020. The copyright holder for this preprint (which was not certified by peer review) is the author/funder, who has granted medRxiv a license to display the preprint in perpetuity.

\section{It is made available under a CC-BY-NC-ND 4.0 International license .}

425

426 Figure 3

LEGEND

- Global ECSA

- Coastal Kenya

- Northern Kenya

- Child PIN01

- Child PIN03

- Child NGE07

- Child NGE17
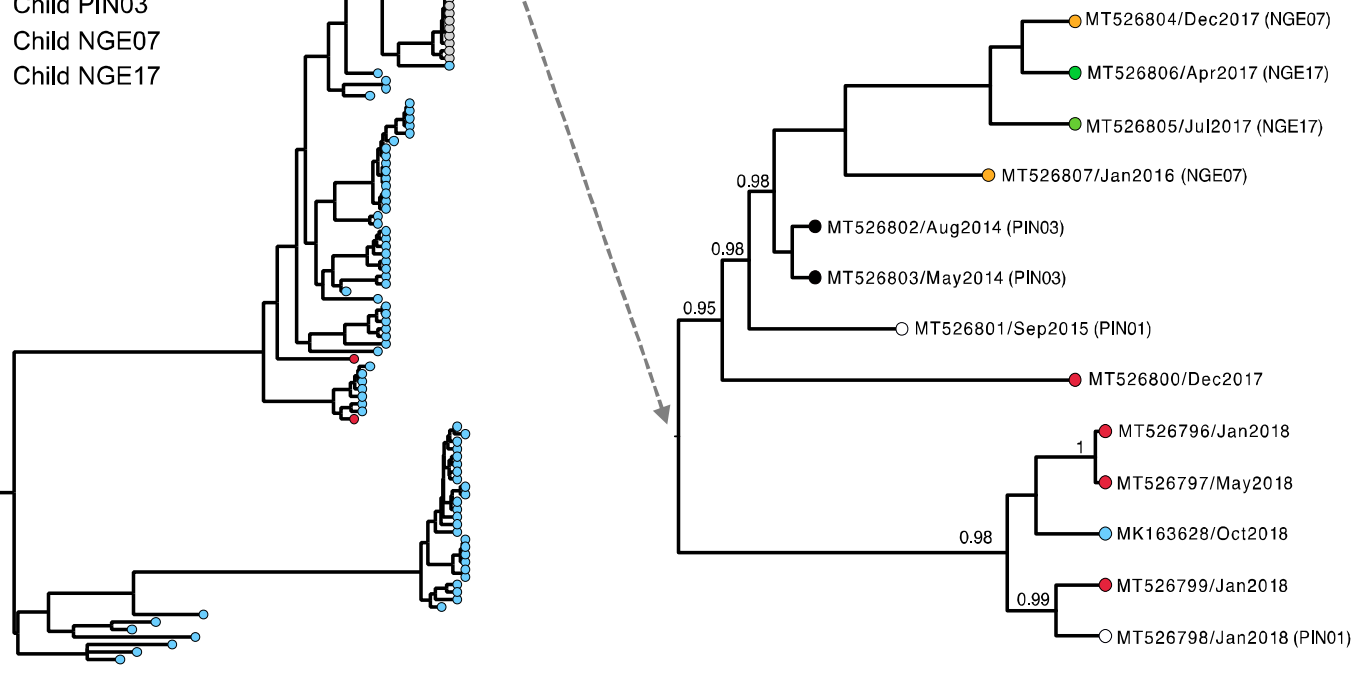

$\begin{array}{lllllllll}1950 & 1960 & 1970 & 1980 & 1990 & 2000 & 2010 & 2020\end{array}$

$\begin{array}{lllllll}2013 & 2014 & 2015 & 2016 & 2017 & 2018 & 2019\end{array}$ 